Article

\title{
Crustacean Decapod Assemblage Associated with Seagrass (Zostera marina) Beds in Southern Waters of Korea
}

\author{
Joo Myun Park ${ }^{1, * \mathbb{D}}$, Seok Nam Kwak ${ }^{2}$ and Ralf Riedel ${ }^{3}$ \\ 1 Dokdo Research Center, East Sea Research Institute, Korea Institute of Ocean Science \& Technology, \\ Uljin 36315, Korea \\ 2 Environ-Ecological Engineering Institute Co. Ltd., Busan 48280, Korea; seoknam@eeei.kr \\ 3 S\&R Consultancy, Ocean Springs, Mississippi, MS 39564, USA; ralf.riedel@usm.edu \\ * Correspondence: joomyun.park@kiost.ac.kr or joomyun@gmail.com; Tel.: +82-54-780-5344
}

Received: 21 December 2019; Accepted: 26 February 2020; Published: 28 February 2020

\begin{abstract}
Decapod assemblages in Zostera marina beds from two bays adjacent to unvegetated habitats were investigated to assess their influence on decapod assemblages. Thirty-eight decapod species belonging to four taxa were collected using a small beam trawl at four habitat types from two different locations off the coast of Namhae Island, South Korea. Dominant decapod taxon at all habitats was the caridean shrimps, with Eualus leptognathus, Heptacarpus pandaloides, Latreutes anoplonyx, La. Laminirostris, and Palaemon macrodactylus being the most abundant caridean species. Crabs were characterized with the highest biomass, but with moderate species richness and abundance. Penaeoid and sergestoid shrimps only accounted for $<1 \%$ of the total decapod abundance. The number of species and their abundance of decapod assemblages varied greatly by habitat type, season, and diel patterns, but not diversity. Species number and abundance peaked in seagrass beds of southern exposed bays during the autumn and were lowest in unvegetated habitats during the summer months. Diel decapod catch rates were higher at night. Dense seagrass vegetation and nighttime supported higher decapod mean densities, but not species richness and diversity. Multivariate analyses revealed that habitat type and season significantly affected the structure of decapod assemblages, but diel patterns had a minor influence. Among decapod species, Pa. macrodactylus and Pugettia quadridens characterized the decapod assemblages in seagrass beds at the northern semi-closed bay, while Telmessus acutidens, Crangon affinis, Cr. hakodatei, Charybdis (Charybdis) japonica, and Portunus sanguinolentus were significantly associated with both vegetated and unvegetated habitats at the southern exposed bay, with the former two species more abundant during the colder season.
\end{abstract}

Keywords: decapod assemblage; Zostera marina; Namhae Island; seagrass vegetation; day/night change

\section{Introduction}

Seagrass beds have been shown to be highly productive marine habitats, common in estuarine and shallow marine coastal ecosystems throughout the world [1,2]. Among seagrass species, Zostera marina is widespread in temperate coastal areas of the Western Pacific, providing shelter for many marine animals, especially their juveniles [3-6]. Seagrass meadows' physical complexity also provides protection from predators [7-9] and allows coexistence of species occupying different ecological niches [10]. As a further benefit, seagrass beds provide nursery grounds and feeding opportunities for vertebrate and invertebrate species, many of which are of commercial and recreational value [4,11-13].

Studies on abundance patterns and community structure according to vegetation cover have shown a higher diversity of vertebrates and invertebrates in vegetated habitats $[10,14,15]$. Since 
seagrasses stabilize sediments from tidal currents and wave action [16,17], they provide a suitable habitat for benthic invertebrates [18,19]. The quality of vegetative cover and the complexity of the physical habitat also have been shown to influence faunal assemblages. Recent studies of faunal assemblages on seagrass-macroalgal beds and its adjacent habitats have shown faunal assemblages structures determined by phenological parameters of seagrass [20,21], substrate structures [22,23], geographical features around seagrass-microalgal beds [24], and other hydrographic factors [25,26]. Further investigations on trophic relationships have also revealed the roles of seagrass habitat complexity structuring fish and macroinvertebrate assemblages [27-29].

Habitat structure complexity has often been associated with biodiversity [30], with a more complex habitat providing a wider range of niches, allowing for a higher number of resident species [31-34]. The diversity of decapod assemblages, similarly, has been shown to be higher in seagrass beds compared with that in non-vegetated habitats. Bloomfield and Gillanders [35] reported similar faunal assemblages between non-vegetated and seagrass habitats in southern Australia, with the caveat of higher loss rates of species richness and abundance in seagrass habitats. More recently, Park and Kwak [36] showed that seagrass beds adjacent to both tidal flats and rocky shores supported greater decapod abundances and diversities than adjacent unvegetated habitats. The importance of large seagrass beds to abundance and diversity [36-38] may be due to the high abundances of eelgrass residents [39]. Comparative studies of decapod assemblages between vegetated and unvegetated seagrass habitats have shown bare habitats with fewer species [36] and associated with considerable diel and seasonal variations in abundance and assemblage structure [36,40-42].

Extensive seagrass beds are common in Namhae Island, South Korea, providing shelter for small fish and invertebrates [43-45]. Although a number of studies comparing fish and decapod assemblages in seagrass meadows have been conducted globally $[39,40,46-50]$, few such studies have been conducted in the eelgrass beds of South Korean waters. Of the few, the focus was limited to estimating the effects on fish communities $[36,43,51]$. Studies on the effects on decapod diversity, including assessment of bottom sediment structure, presence of seagrasses, and hydrodynamic features, such as water temperature, tidal current, and seasonal storms, might provide key insight into the factors influencing the maintenance of decapod assemblages [52].

In this study, we compared decapod assemblages in seagrass beds adjacent to tidal flats and rocky shores with unvegetated habitats in structuring decapod assemblages. More specifically, we a) associated the effects of geographical locations, habitat types, seasons, and diel patterns with assemblage structure; and b) compared diversity and abundance patterns with habitat. We anticipate this study to aid in understanding the implications of habitat complexity in resource management and conservation of decapods in Korea.

\section{Materials and Methods}

\subsection{Study Area}

Data for this study were gathered from a bay of Namhae Island and one of the adjacent Changseon-Do Island, South Korea, with two study sites within each bay (Figure 1). Bays were comprised of a northern semi-enclosed (Dongdae Bay) and southern exposed (Aenggang Bay) body of water. Dongdae Bay is geographically rich and inland-facing, rich in tidal flats, rocky shores, small islands and reefs. Aenggang Bay is exposed to open ocean from a southern inlet, allowing seawater circulation to the bay. The two study sites in each bay were seagrass beds adjacent to tidal flats $(\mathrm{DS}(\mathrm{t}))$ and to rocky shore (DS(r)) at Dongdae Bay, and seagrass beds (AS) and unvegetated habitat (AU) at Aenggang Bay (Figure 1). Dongdae Bay sediment composition consists of compact particles (e.g., clay-silt). Sediment at Aenggang Bay, conversely, mostly comprises coarse particles (Kim et al., unpublished data). Seagrass beds from both bays are characterized by Zostera marina, forming subtidal habitats $(2.7-3.3 \mathrm{~km}$ in width) in shallow water $(<5 \mathrm{~m})$. Seagrass biomass fluctuate with season, peaking during the spring, and seagrass density. Biomass is typically five times higher at Dongdae Bay 
than at Aenggang Bay [45]. Typical water temperature fluctuations are between $7.4^{\circ} \mathrm{C}$ and $27.7^{\circ} \mathrm{C}$ at Dongdae Bay and between $7.7^{\circ} \mathrm{C}$ and $30.7^{\circ} \mathrm{C}$ at Aenggang Bay. Salinity is between 19.5 and $34.2 \mathrm{psu}$ (practical salinity unit) at Dongdae Bay and between 16.5 and 34.8 psu at Aenggang Bay. At both bays, values in the summer are lowest for salinity [45].

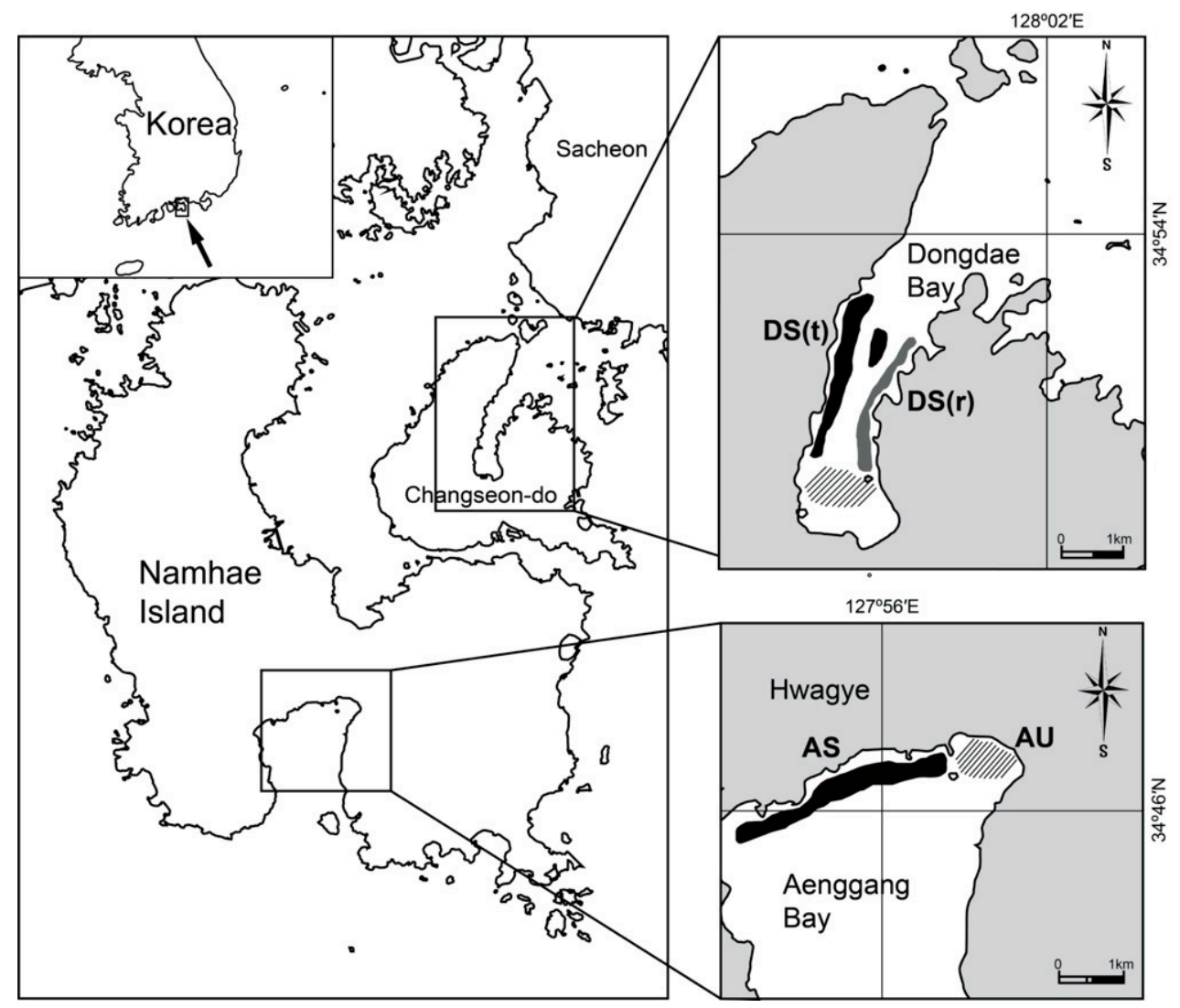

Figure 1. Namhae Island, South Korea, area of investigation. Black area = seagrass bed adjacent tidal flat $(D S(t), A S)$, gray area = seagrass bed adjacent rocky shore $(D S(r))$, oblique area = unvegetated site (AU).

\subsection{Sampling}

Crustacean decapod samples were collected monthly in 2005 using a 3-m beam trawl with 1.9-cm mesh surrounded by a $0.6-\mathrm{cm}$ mesh liner. Tows (four; 6 min duration) both during the day (between 10:00 and 12:00) and night (between 20:00 and 22:00) at spring tide in all habitats were conducted, with estimated $280 \mathrm{~m}^{2}$ coverage per sampling event. A total of 384 beam trawl hauls were conducted during the study period. The number of individuals per $100 \mathrm{~m}^{2}$ was the variable recorded. A solution of 5\% formalin with seawater at sampling, followed by $70 \%$ ethanol for long-term storage was used to preserve specimens. All individual decapods were identified to the lowest taxa possible and weighed to the nearest milligram. All scientific names were checked against the WoRMS database [53].

\subsection{Data Analyses}

The Shannon-Wiener index ( $\mathrm{H}^{\prime}$; [54]) was used to estimate community-level diversity. Prior to ANOVA analysis, the assumption of homogeneity of variance was tested using Levene's test [55]. Since there was no evidence for heteroschedasticity, three-way analysis of variance (ANOVA) was used to assess spatial and temporal differences in species richness (number of species), abundance (number of individuals), and diversity. Station (combined factor of location and habitat; i.e., study location across seagrass vegetation), season, and diel patterns were fixed factors, with Tukey's honest significant different (HSD) test for post-hoc ANOVA tests. Abundances for all species were $\log (\mathrm{x}+$ 
1)-transformed. Three stations were seagrass bed in Dongdae Bay, and both were seagrass bed and bare habitat in Aenggang Bay. The four seasons were winter (December-February), spring (March-May), summer (June-August), and autumn (September-November).

Inferential and descriptive analyses were performed to further assess abundance trends with diel patterns, seasons, and habitat. Permutation multivariate analyses of variance (PERMANOVA) on $\log ($ abundance +1$)$ based on Bray-Curtis similarity matrices were conducted [56]. Analysis factors for the PERMANOVA were location (two fixed levels: Aenggang and Dongdae), habitat (nested within location, three random levels), season (four fixed levels: winter, spring, summer, and autumn), and diel patterns (two fixed levels: day and night). Similarity matrices were used in a PERMANOVA to test for factor effects. In cases in which PERMANOVA detected a significant difference at the 0.05 level, posteriori pairwise PERMANOVA comparisons were used to determine which interaction terms differed significantly among variables within each level of factors. PERMANOVA assigns components of variation (COV) of differing magnitudes to the main factors and interaction between combinations of main factors. The larger COV indicates the greater the influence of a particular factor or interaction term on the structure of the data [57]. The metric multidimensional scaling (mMDS) ordination technique was used to visualize factor effects. To assess statistical significance among factor levels, a canonical analysis of principal coordinates (CAPs) was used [57]. Correlation coefficients between each factor and the canonical axis were used as evidence for species contributions to observe differences. Individual species with both correlations higher than 0.4 and total abundance larger than $1 \%$ were plotted on CAP axes 1 and 2 for additional visualization of results.

Statistical software used was Systat (Systat version 18, SPSS Inc., Chicago, IL, USA) and PRIMER v7 with the PERMANOVA+ module [57,58]. A 0.05 level for statistical significance was used in analyses.

\section{Results}

\subsection{Decapod Species Composition}

Thirty-eight decapod species from four taxa were sampled in this study (Table 1). Ranks by number were Caridea (19 species), followed by Brachyura (13 species), Penaeoidea (4 species), and Sergestoidea (2 species). Aenggang Bay seagrass bed (AS) yielded the largest number of species, and the lowest at the seagrass bed adjacent to the rocky shore at Dongdae Bay (DS(t)). The seagrass bed of Aengang Bay produced the largest abundance of decapods and the lowest at the bare habitat of Aengang Bay (AU). Overall, the study areas were dominated by the Caridea genera of Eualus, Heptacarpus, and Latreutes. The species with highest abundance at all study sites were Heptacarpus pandaloides, followed by Eualus leptognathus, Latreutes anoplonyx, and La. laminirostris. Among decapods, Palaemon species was dominant at Dongdae Bay, and Crangon affinis and Portunus sanguinolentus were dominant at Aengang Bay (Table 1).

\subsection{Spatio-temporal Changes in Species Richness, Abundance, and Diversity}

Abundance and mean richness varied by factors of station, season, and diel patterns, but not diversity. Three-way ANOVA showed species richness and abundance of decapod assemblage differed significantly among stations, seasons, and diel patterns, except species richness between day and night. Diversity patterns were not significant for any factors (Table 2). No two- or three-way interactions were significant between most factors. Only the station $\times$ day/night interaction for abundance had a significant influence on decapod assemblage (Table 2). 
Table 1. Decapod species and total abundance (per $100 \mathrm{~m}^{-2}$ ) in seagrass beds adjacent to tidal flat (DS(t)) and rocky shore (DS(r)) of Dongdae Bay, seagrass beds (AS) and adjacent habitats to the unvegetated areas (AU) of Aenggang Bay, Namhae Island, South Korea.

\begin{tabular}{|c|c|c|c|c|c|}
\hline \multirow[b]{2}{*}{ Taxa } & \multirow[b]{2}{*}{ Species Name } & \multicolumn{2}{|c|}{ Dongdae Bay } & \multicolumn{2}{|c|}{ Aenggang Bay } \\
\hline & & $\operatorname{DS}(t)$ & DS(r) & AS & AU \\
\hline \multirow[t]{4}{*}{ Penaeoidea } & Metapenaeopsis tenella & 3.3 & 3.3 & 3.9 & 1.1 \\
\hline & Mierspenaeopsis hardwickii & & 0.6 & & \\
\hline & Penaeus japonicus & & & 0.6 & \\
\hline & Trachysalambria curvirostris & 3.9 & & 0.6 & \\
\hline \multirow[t]{2}{*}{ Sergestoidea } & Acetes chinensis & 5.6 & & 1.7 & 3.9 \\
\hline & Acetes japonicus & 0.6 & & 0.6 & \\
\hline \multirow[t]{19}{*}{ Caridea } & Alpheus brevicristatus & 2.2 & & 0.6 & 1.1 \\
\hline & Alpheus digitalis & & 0.6 & 1.1 & \\
\hline & Crangon affinis & 1.7 & 2.2 & 76.7 & 92.8 \\
\hline & Crangon hakodatei & 0.6 & & 24.4 & 14.4 \\
\hline & Eualus leptognathus & 1380.6 & 544.4 & 347.2 & 9.4 \\
\hline & Eualus middendorffi & 3.9 & 1.7 & & \\
\hline & Hayashidonus japonicus & & & 7.8 & 3.3 \\
\hline & Heptacarpus futilirostris & 61.7 & 0.6 & 16.7 & 1.1 \\
\hline & Heptacarpus pandaloides & 2462.2 & 925.0 & 5067.2 & 882.2 \\
\hline & Heptacarpus rectirostris & 17.8 & 7.2 & 108.9 & 0.6 \\
\hline & Latreutes anoplonyx & 334.4 & 578.3 & 2220.6 & 106.1 \\
\hline & Latreutes laminirostris & 415.6 & 185.6 & 123.9 & 52.8 \\
\hline & Latreutes planirostris & 0.6 & & 3.3 & \\
\hline & Leptochela gracilis & & & 0.6 & \\
\hline & Lysmata vittata & & 0.6 & 0.6 & \\
\hline & Palaemon carinicauda & 1.1 & 1.7 & & \\
\hline & Palaemon macrodactylus & 224.4 & 46.7 & 4.4 & 5.6 \\
\hline & Palaemon orientis & 18.9 & 3.9 & & \\
\hline & Palaemon ortmanni & 92.8 & 30.6 & 40.0 & 8.3 \\
\hline \multirow[t]{15}{*}{ Brachyura } & Arcania undecimspinosa & & & & 0.6 \\
\hline & Charybdis (Charybdis) japonica & 5.0 & 8.3 & 94.4 & 20.0 \\
\hline & $\begin{array}{c}\text { Charybdis (Charybdis) } \\
\text { sagamiensis }\end{array}$ & & & 3.3 & \\
\hline & Hemigrapsus penicillatus & 20.0 & 11.1 & 6.1 & 0.6 \\
\hline & Hemigrapsus sanguineus & & & & 0.6 \\
\hline & Paradorippe granulata & & & 0.6 & \\
\hline & Pilumnus minutus & & 0.6 & & \\
\hline & Portunus sanguinolentus & 5.0 & & 28.9 & 2.8 \\
\hline & Portunus trituberculatus & & & 1.7 & 1.1 \\
\hline & Pugettia quadridens & 33.3 & 26.1 & 23.3 & 1.7 \\
\hline & Telmessus acutidens & 11.1 & 1.1 & 35.0 & 2.8 \\
\hline & Thalamita sima & & & 8.3 & 1.1 \\
\hline & Xanthidae sp. & 0.6 & & & \\
\hline & Total & 5106.7 & 2380.0 & 8252.8 & 1213.9 \\
\hline & Number of species & 25 & 21 & 30 & 23 \\
\hline
\end{tabular}

Tukey's post-hoc tests indicated that mean species richness was lower at unvegetated habitat than seagrass beds in Aenggang Bay, and during summer than autumn (Figure 2). Mean abundance was the highest at seagrass beds than unvegetated habitats in Aenggang Bay, and during autumn than summer (Figure 2). Diel patterns in decapod assemblage showed that only decapod abundance was significantly higher during the night than day (Figure 2). No patterns in diversity were found with all three factors combined (Figure 2). 
Table 2. Abundance $\left(100 \mathrm{~m}^{-2}\right)$, number of species, and diversity three-way ANOVA for decapod assemblages in South Korea. Boldface values are significance at $p<0.05$.

\begin{tabular}{ccccccccc}
\hline & & \multicolumn{2}{c}{ Species Richness } & \multicolumn{2}{c}{ Abundance } & \multicolumn{2}{c}{ Diversity } \\
Source & df & $\mathbf{F}$ & $\boldsymbol{p}$ & $\mathbf{F}$ & $\boldsymbol{p}$ & $\mathbf{F}$ & $\boldsymbol{p}$ \\
\hline Main test & & & & & & & \\
Station (St) & 2 & 3.373 & $\mathbf{0 . 0 3 0}$ & 5.930 & $\mathbf{0 . 0 0 5}$ & 1.269 & 0.289 \\
Season (Se) & 3 & 3.035 & $\mathbf{0 . 0 3 7}$ & 7.318 & $\mathbf{0 . 0 0 1}$ & 0.385 & 0.764 \\
Day $/$ Night (D/N) & 1 & 0.004 & 0.953 & 4.513 & $\mathbf{0 . 0 3 9}$ & 0.266 & 0.608 \\
Interactions & & & & & & & \\
$\quad$ St $\times$ Se & 6 & 1.085 & 0.383 & 2.245 & 0.052 & 1.178 & 0.117 \\
St $\times \mathrm{D} / \mathrm{N}$ & 2 & 2.319 & 0.108 & 5.186 & $\mathbf{0 . 0 0 9}$ & 1.132 & 0.330 \\
Se $\times \mathrm{D} / \mathrm{N}$ & 3 & 0.885 & 0.455 & 1.228 & 0.309 & 0.221 & 0.882 \\
$\mathrm{St} \times \mathrm{Se} \times \mathrm{D} / \mathrm{N}$ & 5 & 0.298 & 0.912 & 1.212 & 0.316 & 0.470 & 0.797 \\
\hline
\end{tabular}
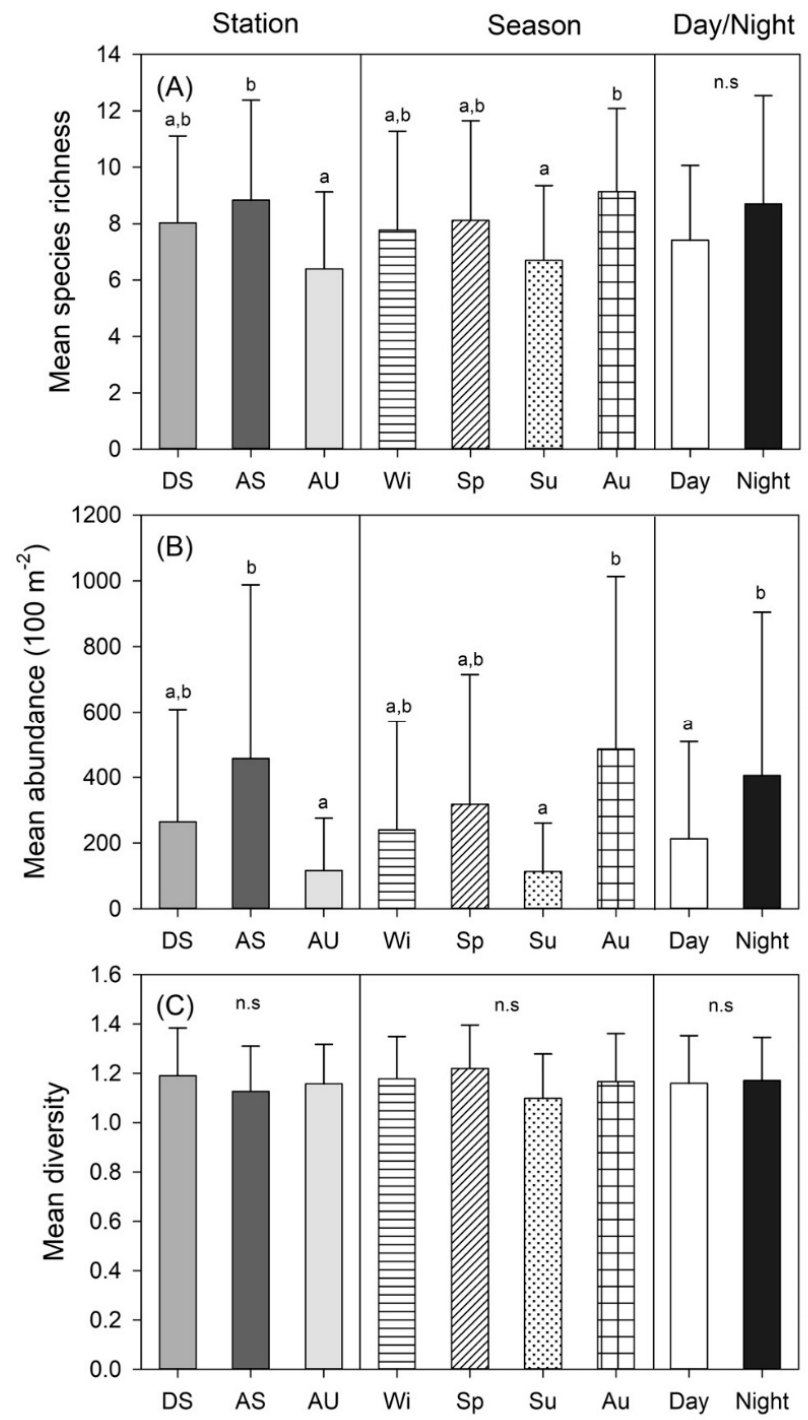

Figure 2. Mean species richness (A), abundance (B), and diversity (C) of decapod assemblages with station, season, and diel patterns. DS = seagrass beds in Dongdae Bay, AS = seagrass bed in Aenggang Bay, $\mathrm{AU}=$ unvegetated habitat in Aenggang Bay; $\mathrm{Wi}=$ winter, $\mathrm{Sp}=$ spring, $\mathrm{Su}=$ summer, $\mathrm{Au}=$ autumn. 


\subsection{Decapod Assemblage Structure}

PERMANOVA tests revealed decapod assemblages were significantly associated with study location, habitat type, and season, with COV of location being the highest, indicating the strongest factors determining variation within samples (Table 3). Only one statistically significant two-way interaction between location and season was observed (Table 3). Pairwise comparisons of location and season showed evidence of differences in decapod assemblage structures between Dongdae and Aenggang bays during spring, summer, and autumn (Table 4). Significant differences between seasons within each location were also observed, except between winter and spring at both locations, and autumn versus other seasons at Dongdae Bay (Table 4). At Dongdae Bay, only differences between spring and summer and between winter and summer were significant. Seasonal comparisons between colder (winter and spring) and warmer (summer and autumn) seasons, and within warmer seasons (summer and autumn) were significant at Aenggang Bay (Table 4).

Table 3. Mean squares (MS), pseudo-F ratios, significance levels ( $p$ ), and components of variation (COV) for PERMANOVA tests using Bray-Curtis similarity matrices from abundance of decapod assemblages showing differences in location (Lo), habitat (Ha nested within Lo), season (Se), day/night (D/N), and interactions terms; bold letters indicate significance at $p<0.05$.

\begin{tabular}{cccccc}
\hline Source & df & MS & Pseudo-F & $p$ & COV \\
\hline Main test & & & & & \\
Lo & 1 & 15294.0 & 9.538 & $\mathbf{0 . 0 0 1}$ & 21.269 \\
$\mathrm{Ha}(\mathrm{Lo})$ & 1 & 3747.8 & 2.337 & $\mathbf{0 . 0 3 1}$ & 12.847 \\
$\mathrm{Se}$ & 3 & 6363.6 & 3.969 & $\mathbf{0 . 0 0 1}$ & 16.936 \\
$\mathrm{D} / \mathrm{N}$ & 1 & 2968.8 & 1.851 & 0.086 & 6.761 \\
Interactions & & & & & \\
Lo $\times$ Se & 3 & 4450.4 & 2.775 & $\mathbf{0 . 0 0 1}$ & 18.522 \\
Lo $\times \mathrm{D} / \mathrm{N}$ & 1 & 3102.2 & 1.935 & 0.074 & 11.045 \\
$\mathrm{Ha}(\mathrm{Lo}) \times \mathrm{Se}$ & 3 & 2404.0 & 1.499 & 0.073 & 14.443 \\
$\mathrm{Ha}(\mathrm{Lo}) \times \mathrm{D} / \mathrm{N}$ & 1 & 2666.6 & 1.663 & 0.114 & 12.936 \\
Se $\times \mathrm{D} / \mathrm{N}$ & 3 & 2618.4 & 1.633 & 0.065 & 10.017 \\
Lo $\times \mathrm{Se} \times \mathrm{D} / \mathrm{N}$ & 3 & 1568.2 & 0.978 & 0.497 & -2.915 \\
$\mathrm{Ha}(\mathrm{Lo}) \times \mathrm{Se} \times \mathrm{D} / \mathrm{N}$ & 2 & 2297.5 & 1.433 & 0.151 & 18.001 \\
Residual & 54 & 1603.5 & & & 40.044 \\
\hline
\end{tabular}

Table 4. Pairwise PERMANOVA tests for the location-season interaction within each study location, or season; bold letters indicate significance at $p<0.05$.

\begin{tabular}{|c|c|c|c|c|c|c|c|c|}
\hline \multirow[b]{2}{*}{ Location } & \multicolumn{2}{|c|}{ Winter } & \multicolumn{2}{|c|}{ Spring } & \multicolumn{2}{|c|}{ Summer } & \multicolumn{2}{|c|}{ Autumn } \\
\hline & $\mathbf{t}$ & $p$ & $\mathbf{t}$ & $p$ & $\mathbf{t}$ & $p$ & $\mathbf{t}$ & $p$ \\
\hline \multirow[t]{2}{*}{ Dongdae-Aenggang } & 1.509 & 0.063 & 2.296 & 0.008 & 2.5082 & 0.001 & 2.213 & 0.001 \\
\hline & \multicolumn{2}{|c|}{ Dongdae } & \multicolumn{2}{|c|}{ Aenggang } & & & & \\
\hline Season & $\mathrm{t}$ & $\mathrm{P}$ & $\mathrm{t}$ & $\mathrm{P}$ & & & & \\
\hline Winter-Spring & 1.177 & 0.221 & 1.012 & 0.374 & & & & \\
\hline Winter-Summer & 1.648 & 0.011 & 1.764 & 0.008 & & & & \\
\hline Winter-Autumn & 1.245 & 0.151 & 2.878 & 0.002 & & & & \\
\hline Spring-Summer & 1.717 & 0.012 & 1.603 & 0.026 & & & & \\
\hline Spring-Autumn & 1.214 & 0.175 & 2.793 & 0.001 & & & & \\
\hline Summer-Autumn & 1.045 & 0.373 & 2.492 & 0.001 & & & & \\
\hline
\end{tabular}

Metric MDS ordination of similarity of mean decapod assemblages showed clear differences in decapod assemblages by study location, habitat type, season, and the location $\times$ season interaction (Figure 3). Samplings from different locations and habitats showed distinct clustering patterns, indicating no overlaps of the multivariate dispersions between locations or habitats (Figure 3A,B). Taking seasonal data pooled by study location and habitat type also showed clear clustering. Bootstrap 
averages of samples between warmer seasons (i.e., summer and autumn) showed clear separation, compared with the average assemblages between colder seasons (Figure 3C). In addition, samples of seasonal decapod assemblage were clearly divided between warmer and colder seasons along with the $\mathrm{Y}$ axis in mMDS ordination. In terms of the location-season interaction, decapod assemblages displayed discrete groups according to both study location and season in the ordination plot (Figure 3D). Within each study location, Aenggang samples showed clear separation in the summer and autumn, while those in Dongdae showed no apparent groupings.
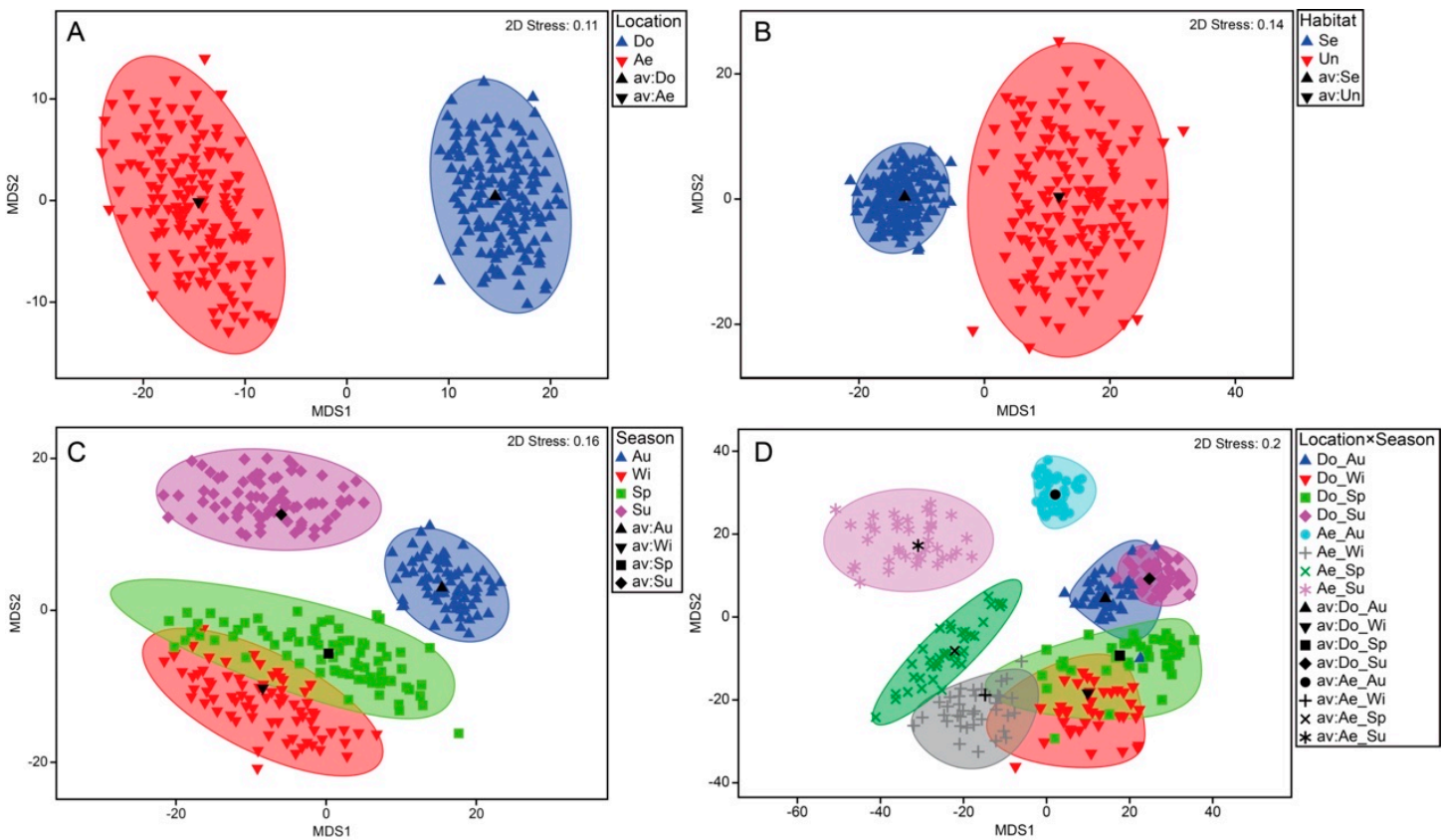

Figure 3. Metric multidimensional scaling (mMDS) for decapod assemblages from the two study locations (A), two habitat types (B), four seasons (C), and eight locations at each season (D); Do = Dongday Bay, Ae = Aenggagn Bay, Se = seagrass bed, $\mathrm{Un}=$ unvegetated habitat; $\mathrm{Wi}=$ winter, $\mathrm{Sp}=$ spring, $\mathrm{Su}=$ summer, $\mathrm{Au}=$ autumn.

Canonical analyses on principal coordinates were performed on significant interactions as a further test on PERMANOVA analyses. The CAP plot for the location-season interaction showed strong evidence for factor group separation (Figure 4). Palaemon macrodactylus and Pugettia quadridens contributed to separate the sites of Dongdae Bay from those in Aenggang Bay. Telmessus acutidens, two crangonid shrimps ( $\mathrm{Cr}$. affinis and $\mathrm{Cr}$. hakodatei), and two portunid crabs (Ch. japonica and Portunus trituberculatus) characterized the decapod assemblages in Aenggang Bay (Figure 4). Weak seasonal differences in decapod assemblages were found at Dongdae Bay, although there were some trends on species contribution of $P a$. macrodactylus and $P u$. quadridens on colder and warmer season assemblages, respectively. Conversely, clear seasonal classifications in decapod assemblages were evident at Aenggang Bay sites. Te. acutidens and Cr. affinis contributed to the colder season samples, and Cr. hakodatei, Ch. Japonica, and Po. trituberculatus to the warmer season samples, regardless of seagrass vegetation (Figure 4).

\section{Discussion}

Dominant caridean shrimps were Ha. pandaloides, La. anoplonyx, Eu. leptognathus, La. laminirostris, and $\mathrm{Pa}$. macrodactylus, and abundant crab species were $\mathrm{Ch}$. japonica, $\mathrm{Pu}$. quadridens, and Te. acutidens. Similar community structures from other South Korean regions were reported. Heptacarpus, Latreutes, Eualus, and Palaemon were the dominant shrimp genera at the seagrass habitats in Kwang Bay and Jinhae Bay $[4,36,59]$. Charybdis (Charybdis) japonica, Pu. quadridens, and Te. acutidens were the common 
crab species at the seagrass beds of Jinhae Bay, but they were not in adjacent unvegetated areas of the bay [36]. Compared with seagrass beds of temperate regions worldwide, the genera Eualus, Heptacarpus, and Latreutes were the principally North Pacific caridean genera often abundant in Zostera meadows [42]. Crangon and Palaemon also dominated the decapod communities of seagrass beds in Western Port Bay, Australia [5,60]. Charybdis (Charybdis) japonica and Pu. quadridens, in particular, were the seagrass-dependent crab species in northwestern Pacific regions [61,62]. The above taxonomical groups, therefore, show common decapods inhabiting seagrass beds of temperate Pacific regions, regardless of locations.

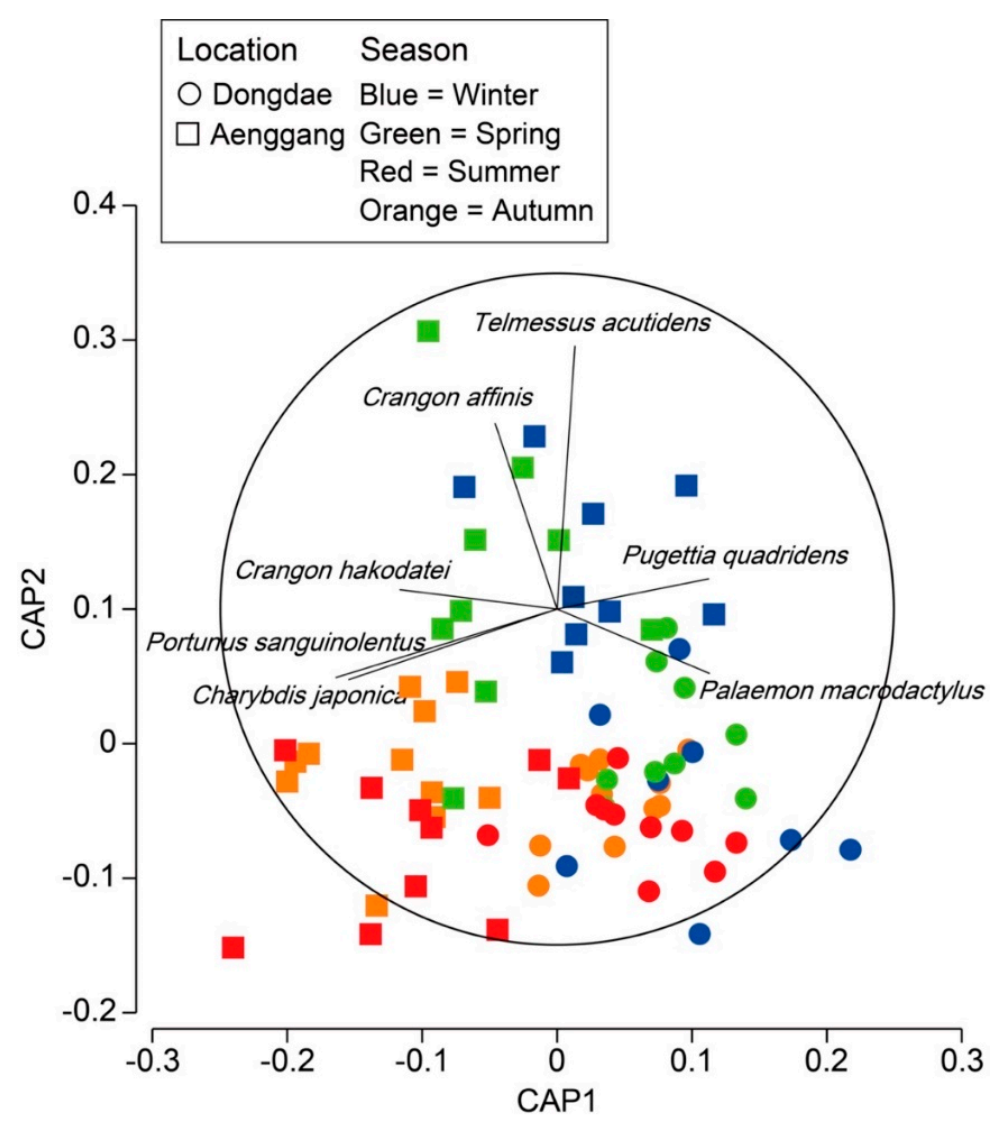

Figure 4. Ordination plots for canonical analysis of principal coordinates of decapod assemblage location-season interaction term.

Seagrass beds are highly productive, showing higher abundances and diversity of marine organisms compared with bare habitats $[6,36,63]$. This is due to the higher capacity of seagrass vegetation in supporting higher abundance and richness of faunal assemblages [39]. This study corroborated the expected by showing higher species richness and abundance in seagrass beds. There were also tendencies of differences in species richness and abundance between seagrass beds within Dongdae Bay. No evidence of differences in diversity, however, were evident among habitat types. Several studies have shown significantly higher decapod abundances at vegetated habitats $[35,36]$. Park and Kwak [36] documented that decapod abundances within seagrass habitats were also significantly influenced by habitat structures associated with adjacent environments, where seagrass bed associated with vegetated tidal flats had a higher decapod abundance than seagrass beds adjacent to rocky shores or unvegetated habitats. Physical habitat structure (i.e., both seagrass vegetation and adjacent environment), therefore, is one of the main forces driving abundance of coastal marine animals in seagrass habitat [64]. 
High seagrass biomass is indicative of high species richness and abundance of faunal assemblages in seagrass habitats $[36,65]$, because increased seagrass biomass provides refuge from predation and favors food availability $[6,66]$. Although noticeable differences in seagrass biomass between the two study bays were evident, with Dongdae Bay having higher seagrass biomass than Aenggang Bay [45], species richness and abundance of decapod assemblages were not associated with seagrass density in the study area. Hori et al. [67] reported intermediate, instead of high, seagrass biomass more conducive to increased abundance of faunal communities. Moranta et al. [68], similarly, reported denser meadows hosting higher densities of small-sized fishes, but not necessarily larger adults. Thus, decapod assemblage among seagrass beds in this study may not be influenced solely by seagrass biomass, but other physical factors, such as shoreline characteristics, may influence decapod abundance. In Cádiz Bay of southwestern Spain, inner bay habitats with higher vegetative cover and relatively limited water renewal support lower species richness compared with the outer bay [69]. Similarly, in this study, higher accessibility due to exposure to open ocean promoted the occurrence of marine organisms, whereas enclosed bays hindered habitat accessibility to marine fauna. Habitat accessibility to macroinvertebrates has also been shown to be a factor of exposure levels in seagrass beds [24]. Thus, the effects of coastline patterns and meadow structure may interact, producing the patterns in decapod communities observed in this study.

Multivariate analyses agreed with analyses from ANOVA in that decapod assemblage structure was influenced by study location, habitat type, and season, especially between colder (winter and spring) and warmer (summer and autumn) seasons. Such a difference, however, was likely not only due to vegetative cover. The differences in assemblage may have also been due to habitat use variation by individual decapod species in different habitats and seasons. Canonical analysis of principal coordinates showed strong associations between decapod assemblages and habitat, as well as season. As an example, crangonid shrimps were limited to Aenggang Bay, whereas $P u$. quadridens and $P a$. macrodactylus were highly associated with seagrass beds of Dongdae Bay. In this study, the differences of decapod assemblages are likely associated with sediment compositions (i.e., compact verse coarse particles) and degree of exposure to open sea between study locations [45]. Among decapod species, crangonid shrimps showed sediment preferences in coarse sand bottoms related to its borrowing ability $[70,71]$, whereas Palaemon species inhabited mainly seagrass-covered beds $[72,73]$ with mud bottoms [74]. De La Rosa et al. [69] also showed structures of decapod assemblages influenced by variability of granulometric composition in Cádiz Bay, southwestern Spain, with low granulometric variability and fine sediment associated with structural heterogeneity. In addition, high circulation at exposed habitats (i.e., Anggang Bay) may allow accessibility for various marine species, including swimming crabs (Portunidae). Since our sampling locations all provided adequate habitats, the observed differences in assemblage may have been due to different sediment structure and habitat exposures at each location. Nonetheless, several minor decapod groups, including Eualus and Palaemon shrimps, and $P u$. quadridens and Te. acutidens crabs, consistently preferred vegetated habitats, regardless of geographical difference and sediment compositions.

Seasonal variation in both species richness and abundance was significant for seagrass decapod communities, with similar patterns among winter, spring, and autumn, but considerably lower in the summer. The pattern observed was probably more due to stable and dense vegetative cover and less to hydrographic factors [52]. Lower abundance of seagrass organisms during summer suggests that some marine animals select against high temperatures [75] or low salinities [76]. Decapod assemblages, however, were highly variable between colder and warmer seasons, especially at Aenggang Bay. This seasonal structural difference was mainly due to contributions of several crab species in each season; i.e., swimming crabs (Portunidae) were more associated with decapod assemblage during the warmer season, while Telmessus acutidens contributed to colder season assemblages. Spawning, coinciding with development of the seagrass, may have been the driver for the observed pattern $[45,77,78]$, probably due to migration from deeper waters to shallow habitats for reproduction. In addition, although two crangonid shrimps were highly associated with Aenggang Bay, their occurrence pattern between colder 
and warmer seasons was apparent for this bay. Such temporal segregations among sympatric species have also been reported for palaemonid shrimps, with varying freshwater inputs and salinity between dry and wet season in estuarine habitats [79], allowing coexistence of closely related species in a given habitat through resource partitioning [80].

Overall abundance of decapods was higher at night than during the day. No significant diel patterns in assemblage structure, however, were evident. Decapod assemblage patterns in seagrass beds and shallow marsh creeks from sub-tropical and temperate estuaries supported our observation $[40,42,81-83]$. Diel difference in abundance might relate to diurnal changes in decapod behavior associated with variation in light intensity, turbidity, and tide forcing $[84,85]$. Rountree and Able [81] reported that young-of-the-year decapod were significantly more abundant at night due to their nocturnal movement into shallow marsh creeks. From both field and laboratory observations, Bauer [42] found that mean abundance of caridean shrimps from seagrass meadows was consistently higher at night, because of nocturnal emergence from daytime burrows. Several studies also reported nocturnal movement from substrate into the water column [86,87], increasing abundance of epiphytic crustaceans at night in shallow seagrass habitats [82,88]. More recently, Hampel et al. [83] showed densities of faunal assemblages influenced by the interplay of light intensity and tidal cycles in an intertidal salt marsh creek, with the highest densities during low tide and at night.

\section{Conclusions}

This study provides important insights into the spatio-temporal variabilities of decapod assemblages in seagrass beds and unvegetated areas from two locations at Namhae Island in South Korean waters. Findings herein showed that habitat type, location, and season, driven principally by variations in the abundance of common decapod species, influence decapod assemblage structure. Moreover, density of seagrass beds and abundance of decapods were positively related, with higher abundances during the night. Since seagrass habitats are associated with high abundance of ecologically and economically important marine organisms, preservation and management of such habitats must be a priority. Investigations of relationships between faunal assemblages and habitat types, such as this, establish much-needed baselines for future research and management interventions toward marine biodiversity, especially in areas where research is limited or lacking, as in South Korean waters.

Author Contributions: Methodology, validation, formal analysis and writing—original draft preparation, J.M.P.; writing-review and editing, S.N.K. and R.R. All authors have read and agreed to the published version of the manuscript.

Funding: This research was funded by the Korea Institute of Ocean Science and Technology (grant numbers PE99813 and PE99763).

Acknowledgments: Ha Won Kim and Bong Jun Seong are thanked for their sampling and analytical contributions. Field protocols were in accordance with the approval of "Research and Training Fishery" in the Ministry of Ocean and Fisheries, Korea.

Conflicts of Interest: The authors declare no conflicts of interest.

\section{References}

1. Thayer, G.; Wolfe, D.; Williams, R. The Impact of Man on Seagrass Systems: Seagrasses must be considered in terms of their interaction with the other sources of primary production that support the estuarine trophic structure before their significance can be fully appreciated. Am. Sci. 1975, 63, 288-296.

2. Duarte, C.M.; Marbà, N.; Gacia, E.; Fourqurean, J.W.; Beggins, J.; Barrón, C.; Apostolaki, E.T. Seagrass community metabolism: Assessing the carbon sink capacity of seagrass meadows. Global Biogeochem. Cy. 2010, 24, GB4032. [CrossRef]

3. Klumpp, D.; Howard, R.K.; Pollard, D. Trophodynamics and nutritional ecology of seagrass communities. In Biology of Seagrasses; Larkum, A., McComb, A., Shepherd, S., Eds.; Elsevier Science Pub.: Amsterdam, The Netherlands, 1989; pp. 394-437. 
4. Huh, S.-H.; AN, Y.-R. Seasonal variation of shrimp (Crustacea: Decapoda) community in the eelgrass (Zostera marina) bed in Kwangyang Bay, Korea. Korean J. Fish. Aquat. Sci. 1997, 30, 532-542.

5. Connolly, R.; Jenkins, G.; Loneragan, N. Seagrass Dynamics and Fisheries Sustainability; CSIRO Publishing: Clayton, VIC, Australia, 1999.

6. Hemminga, M.A.; Duarte, C.M. Seagrass Ecology; Cambridge University Press: Cambridge, UK, 2000.

7. Blaber, S.; Brewer, D.; Salini, J. Fish communities and the nursery role of the shallow inshore waters of a tropical bay in the Gulf of Carpentaria, Australia. Estuar. Coast. Shelf Sci. 1995, 40, 177-193. [CrossRef]

8. Beyst, B.; Hostens, K.; Mees, J. Factors influencing the spatial variation in fish and macrocrustacean communities in the surf zone of sandy beaches in Belgium. J. Mar. Biolog. Assoc. U.K. 2002, 82, 181-187. [CrossRef]

9. Nagelkerken, I.; Roberts, C.M.; Van der Velde, G.; Dorenbosch, M.; Van Riel, M.C.; Cocheret de la Morinière, E.; Nienhuis, P.H. How important are mangroves and seagrass beds for coral-reef fish? The nursery hypothesis tested on an island scale. Mar. Ecol. Prog. Ser. 2002, 244, 299-305. [CrossRef]

10. Orth, R.J.; Heck, K.L.; van Montfrans, J. Faunal communities in seagrass beds: A review of the influence of plant structure and prey characteristics on predator-prey relationships. Estuaries 1984, 7, 339-350. [CrossRef]

11. Edgar, G.J.; Shaw, C. The production and trophic ecology of shallow-water fish assemblages in southern Australia, I. Species richness, size-structure and production of fishes in Western Port, Victoria. J. Exp. Mar. Biol. Ecol. 1995, 194, 53-81. [CrossRef]

12. Guidetti, P.; Bussotti, S. Fish fauna of a mixed meadow composed by the seagrasses Cymodocea nodosa and Zostera noltii in the Western Mediterranean. Oceanol. Acta 2000, 23, 759-770. [CrossRef]

13. Nelson, W. The role of predation by decapod crustaceans in seagrass ecosystems. Kiel. Meeresforsch 1981, 5, 529-536.

14. Polte, P.; Asmus, H. Influence of seagrass beds (Zostera noltii) on the species composition of juvenile fishes temporarily visiting the intertidal zone of the Wadden Sea. J. Sea Res. 2006, 55, 244-252. [CrossRef]

15. Edgar, G.J. The influence of plant structure on the species richness, biomass and secondary production of macrofaunal assemblages associated with Western Australian seagrass beds. J. Exp. Mar. Biol. Ecol. 1990, 137, 215-240. [CrossRef]

16. Orth, R.J. The Importance of Sediment Stability in Seagrass Communities. In Ecology of Marine Benthos; Coull, B., Ed.; University of South Carolina Press: Columbia, SC, USA, 1977; pp. 281-300.

17. Wells, F.; Rose, R.; Lang, S. An analysis of benthic marine invertebrate communities in subtidal seagrass and sand habitats in Shark Bay, Western Australia. Rec. West. Aust. Mus. 1985, 12, 47-56.

18. Boström, C.; Mattila, J. The relative importance of food and shelter for seagrass-associated invertebrates: A latitudinal comparison of habitat choice by isopod grazers. Oecologia 1999, 120, 162-170. [CrossRef]

19. Heck, K., Jr.; Wetstone, G. Habitat complexity and invertebrate species richness and abundance in tropical seagrass meadows. J. Biogeogr. 1977, 4, 135-142. [CrossRef]

20. Attrill, M.J.; Strong, J.A.; Rowden, A.A. Are macroinvertebrate communities influenced by seagrass structural complexity? Ecography 2000, 23, 114-121. [CrossRef]

21. Mateo-Ramírez, Á.; Urra, J.; Marina, P.; Rueda, J.L.; García Raso, J.E. Crustacean decapod assemblages associated with fragmented Posidonia oceanica meadows in the Alboran Sea (Western Mediterranean Sea): Composition, temporal dynamics and influence of meadow structure. Mar. Ecol. 2016, 37, 344-358. [CrossRef]

22. Mateo Ramírez, Á.; García Raso, J.E. Temporal changes in the structure of the crustacean decapod assemblages associated with Cymodocea nodosa meadows from the Alboran Sea (Western Mediterranean Sea). Mar. Ecol. 2012, 33, 302-316. [CrossRef]

23. Mateo-Ramírez, Á.; Urra, J.; Rueda, J.; Marina, P.; Raso, J.G. Decapod assemblages associated with shallow macroalgal communities in the northwestern Alboran Sea: Microhabitat use and temporal variability. J. Sea Res. 2018, 135, 84-94. [CrossRef]

24. Ávila, E.; Yáñez, B.; Vazquez-Maldonado, L.E. Influence of habitat structure and environmental regime on spatial distribution patterns of macroinvertebrate assemblages associated with seagrass beds in a southern Gulf of Mexico coastal lagoon. Mar. Biol. Res. 2015, 11, 755-764. [CrossRef]

25. Kwak, S.N.; Park, J.M.; Im, S.O.; Jawad, L.A. Influences of diel and tidal cycles on fish assemblage in eelgrass (Zostera marina) bed of southern Korea during autumn. Acta Oceanol. Sin. 2018, 37, 40-47. [CrossRef] 
26. Unsworth, R.K.; Collier, C.J.; Henderson, G.M.; McKenzie, L.J. Tropical seagrass meadows modify seawater carbon chemistry: Implications for coral reefs impacted by ocean acidification. Environ. Res. Lett. 2012, 7 , 024026. [CrossRef]

27. Heck, K.L., Jr.; Orth, R.J. Seagrass habitats: The roles of habitat complexity, competition and predation in structuring associated fish and motile macroinvertebrate assemblages. In Estuarine Perspectives; Kennedy, V.S., Ed.; Academic Press: New York, NY, USA, 1980; pp. 449-464.

28. Box, A.; Martin, D.; Deudero, S. Changes in seagrass polychaete assemblages after invasion by Caulerpa racemosa var. cylindracea (Chlorophyta: Caulerpales): Community structure, trophic guilds and taxonomic distinctness. Sci. Mar. 2010, 74, 317-329. [CrossRef]

29. Hindell, J.S.; Jenkins, G.P.; Keough, M.J. Evaluating the impact of predation by fish on the assemblage structure of fishes associated with seagrass (Heterozostera tasmanica) (Martens ex Ascherson) den Hartog, and unvegetated sand habitats. J. Exp. Mar. Biol. Ecol. 2000, 255, 153-174. [CrossRef]

30. Huston, M.A. Biological Diversity: The Coexistence of Species; Cambridge University Press: Cambridge, UK, 1994.

31. Blanchet, H.; de Montaudouin, X.; Lucas, A.; Chardy, P. Heterogeneity of macrozoobenthic assemblages within a Zostera noltii seagrass bed: Diversity, abundance, biomass and structuring factors. Estuar. Coast. Shelf Sci. 2004, 61, 111-123. [CrossRef]

32. Gratwicke, B.; Speight, M. The relationship between fish species richness, abundance and habitat complexity in a range of shallow tropical marine habitats. J. Fish. Biol. 2005, 66, 650-667. [CrossRef]

33. Hull, S.L. Seasonal changes in diversity and abundance of ostracods on four species of intertidal algae with differing structural complexity. Mar. Ecol. Prog. Ser. 1997, 161, 71-82. [CrossRef]

34. May, R.M. Will a large complex system be stable? Nature 1972, 238, 413-414. [CrossRef]

35. Bloomfield, A.; Gillanders, B. Fish and invertebrate assemblages in seagrass, mangrove, saltmarsh, and nonvegetated habitats. Estuaries 2005, 28, 63-77. [CrossRef]

36. Park, J.M.; Kwak, S.N. Seasonal and habitat structures of crustacean decapod assemblages associated with Zostera marina beds in northern Jinhae Bay, Korea. J. Mar. Biol. Assoc. U.K. 2019, 99, 461-471. [CrossRef]

37. Jelbart, J.E.; Ross, P.M.; Connolly, R.M. Fish assemblages in seagrass beds are influenced by the proximity of mangrove forests. Mar. Biol. 2007, 150, 993-1002. [CrossRef]

38. Mazumder, D.; Saintilan, N.; Williams, R.J. Fish assemblages in three tidal saltmarsh and mangrove flats in temperate NSW, Australia: A comparison based on species diversity and abundance. Wetl. Ecol. Manag. 2006, 14, 201-209. [CrossRef]

39. Lazzari, M.A. Epibenthic fishes and decapod crustaceans in northern estuaries: A comparison of vegetated and unvegetated habitats in Maine. Estuaries 2002, 25, 1210-1218. [CrossRef]

40. Krumme, U. Diel and tidal movements by fish and decapods linking tropical coastal ecosystems. In Ecological Connectivity among Tropical Coastal Ecosystems; Negelkerken, I., Ed.; Springer: Dordrecht, The Netherlands, 2009; pp. 271-324.

41. Gray, C.; Chick, R.; McElligott, D. Diel changes in assemblages of fishes associated with shallow seagrass and bare sand. Estuarine Coast. Shelf Sci. 1998, 46, 849-859. [CrossRef]

42. Bauer, R.T. Diel and seasonal variation in species composition and abundance of caridean shrimps (Crustacea, Decapoda) from seagrass meadows on the north coast of Puerto Rico. Bull. Mar. Sci. 1985, 36, 150-162.

43. Huh, S.H.; Kwak, S.N. Species composition and seasonal variations of fishes in eelgrass (Zostera marina) bed in Kwangyang Bay. Korean J. Ichthyol. 1997, 9, 202-220.

44. Yun, S.G.; Huh, S.H.; Kwak, S.N. Species composition and seasonal variations of benthic macrofauna in eelgrass, Zostera marina, bed. Korean J. Fish. Aquat. Sci. 1997, 30, 744-752.

45. Park, J.M.; Kwak, S.N. Seagrass fish assemblages in the Namhae Island, Korea: The influences of seagrass vegetation and biomass. J. Sea Res. 2018, 139, 41-49. [CrossRef]

46. Bell, J.D.; Westoby, M. Importance of local changes in leaf height and density to fish and decapods associated with seagrasses. J. Exp. Mar. Biol. Ecol. 1986, 104, 249-274. [CrossRef]

47. Heck, K.; Able, K.; Fahay, M.; Roman, C. Fishes and decapod crustaceans of Cape Cod eelgrass meadows: Species composition, seasonal abundance patterns and comparison with unvegetated substrates. Estuaries 1989, 12, 59-65. [CrossRef]

48. Worthington, D.G.; Ferrell, D.J.; McNeill, S.E.; Bell, J.D. Effects of the shoot density of seagrass on fish and decapods: Are correlation evident over larger spatial scales? Mar. Biol. 1992, 112, 139-146. [CrossRef] 
49. Sanchez-Jerez, P.; Barbera-Cebrian, C.; Ramos-Espla, A.A. Influence of the structure of Posidonia oceanica meadows modified by bottom trawling on crustacean assemblages: Comparison of amphipods and decapods. Sci. Mar. 2000, 64, 319-326. [CrossRef]

50. Kwak, S.N.; Klumpp, D.W. Temporal variation in species composition and abundance of fish and decapods of a tropical seagrass bed in Cockle Bay, North Queensland, Australia. Aquat. Bot. 2004, 78, 119-134. [CrossRef]

51. Kwak, S.N.; Huh, S.H.; Kim, H.W. Change in fish assemblage inhabiting around Dae Island in Gwangyang Bay, Korea. J. Korean Soc. Mar. Environ. Saf. 2012, 18, 175-184. [CrossRef]

52. De La Rosa, I.L.; Rodríguez, A.; Raso, J.E.G. Seasonal variation and structure of a decapod (Crustacea) assemblage living in a Caulerpa prolifera meadow in Cadiz Bay (SW Spain). Estuar. Coast. Shelf Sci. 2006, 66, 624-633. [CrossRef]

53. Horton, T.; Kroh, A.; Ahyong, S.; Bailly, N.; Boyko, C.B.; Brandão, S.N.; Gofas, S.; Hooper, J.N.A.; Hernandez, F.; Holovachov, O.; et al. World Register of Marine Species (WoRMS); WoRMS Editorial Board: Ostend, Belgium, 2020.

54. Shannon, C.; Weaver, W. The Mathematical Theory of Communication; Illinois University Press: Urbana, IL, USA, 1949.

55. Sokal, R.R.; Rohlf, F.J. Biometry: The Principles and Practice of Statistics in Biological Research; Freeman: New York, NY, USA, 1981.

56. Clarke, K.R.; Somerfield, P.J.; Chapman, M.G. On resemblance measures for ecological studies, including taxonomic dissimilarities and a zero-adjusted Bray-Curtis coefficient for denuded assemblages. J. Exp. Mar. Biol. Ecol. 2006, 330, 55-80. [CrossRef]

57. Anderson, M.; Gorley, R.; Clarke, K. PERMANOVA+ for PRIMER: Guide to Software and Statistical Methods; PRIMER-E Plymouth Marine Laboratory: Plymouth, UK, 2008.

58. Clarke, K.; Gorley, R. PRIMER v7: User Manual/Tutorial; PRIMER-E: Plymouth, UK, 2015.

59. Huh, S.-H.; An, Y.-R. Seasonal variation of crab (Crustacea: Decapoda) community in the eelgrass (Zostera marina) bed in Kwangyang Bay, Korea. Korean J. Fish. Aquat. Sci. 1998, 31, 535-544.

60. Howard, R.K. The trophic ecology of caridean shrimps in an eelgrass community. Aquat. Bot. 1984, 18, 155-174. [CrossRef]

61. Xu, Q.; Guo, D.; Zhang, P.D.; Zhang, X.M.; Li, W.T.; Wu, Z.X. Seasonal variation in species composition and abundance of demersal fish and invertebrates in a Seagrass Natural Reserve on the eastern coast of the Shandong Peninsula, China. Chin. J. Oceanol. Limnol. 2016, 34, 330-341. [CrossRef]

62. Watanabe, Y.; Kawamura, T.; Yamashita, Y. Introduction: The coastal ecosystem complex as a unit of structure and function of biological productivity in coastal areas. Fish. Sci. 2018, 84, 149-152. [CrossRef]

63. Bell, J. Ecology of fish assemblages and fisheries associated with seagrasses. Biol. Seagrasses 1989, 536-564.

64. Guidetti, P. Differences among fish assemblages associated with nearshore Posidonia oceanica seagrass beds, rocky-algal reefs and unvegetated sand habitats in the Adriatic Sea. Estuar. Coast. Shelf Sci. 2000, 50, 515-529. [CrossRef]

65. Klumpp, D.W.; Kwak, S.N. Composition and abundance of benthic macrofauna of a tropical sea-grass bed in north Queensland, Australia. Pac. Sci. 2005, 59, 541-561. [CrossRef]

66. Stoner, A. The role of seagrass biomass in the organization of benthic macrofaunal assemblages. Bull. Mar. Sci. 1980, 30, 537-551.

67. Hori, M.; Suzuki, T.; Monthum, Y.; Srisombat, T.; Tanaka, Y.; Nakaoka, M.; Mukai, H. High seagrass diversity and canopy-height increase associated fish diversity and abundance. Mar. Biol. 2009, 156, 1447-1458. [CrossRef]

68. Moranta, J.; Palmer, M.; Morey, G.; Ruiz, A.; Morales-Nin, B. Multi-scale spatial variability in fish assemblages associated with Posidonia oceanica meadows in the Western Mediterranean Sea. Estuar. Coast. Shelf Sci. 2006, 68, 579-592. [CrossRef]

69. De La Rosa, I.L.; Raso, J.G.; Rodríguez, A. Evolution of a decapod community (Crustacea) of shallow soft bottoms with seaweeds from southern Europe. J. Mar. Biol. Assoc. U.K. 2002, 82, 85-95. [CrossRef]

70. Pinn, E.H.; Ansell, A.D. The effect of particle size on the burying ability of the brown shrimp Crangon crangon. J. Mar. Biol. Assoc. U.K. 1993, 73, 365-377. [CrossRef]

71. Ouellette, C.; Boghen, A.D.; Courtenay, S.C.; St-Hilaire, A. Influence of peat substrate on the distribution and behaviour patterns of sand shrimp, Crangon septemspinosa, under experimental conditions. J. Appl. Ichthyol. 2003, 19, 359-365. [CrossRef] 
72. Berglund, A. Niche differentiation between two littoral prawns in Gullmar Fjord, Sweden: Palaemon adspersus and P. squilla. Ecography 1980, 3, 111-115. [CrossRef]

73. Baden, S.P.; Pihl, L. Abundance, biomass and production of mobile epibenthic fauna in Zostera marina (L.) meadows, western Sweden. Ophelia 1984, 23, 65-90. [CrossRef]

74. Berglund, A.; Bengtsson, J. Biotic and abiotic factors determining the distribution of two prawn species: Palaemon adspersus and P. squilla. Oecologia 1981, 49, 300-304. [CrossRef] [PubMed]

75. Liu, J.; Morton, B. The temperature tolerances of Tetraclita squamosa (Crustacea: Cirripedia) and Septifer virgatus (Bivalvia: Mytilidae) on a sub-tropical rocky shore in Hong Kong. J. Zool. 1994, 234, 325-339. [CrossRef]

76. Matheson, R.E.; Camp, D.K.; Sogard, S.M.; Bjorgo, K.A. Changes in seagrass-associated fish and crustacean communities on Florida Bay mud banks: The effects of recent ecosystem changes? Estuaries 1999, 22, 534. [CrossRef]

77. Yu, C.; Song, H.; Yao, G. The quantity distribution and biological property of Charybdis japonica in the East China Sea. J.Shanghai Fish. Univ. 2005, 14, 40-45.

78. Rasheed, S.; Mustaquim, J. Size at sexual maturity, breeding season and fecundity of three-spot swimming crab Portunus sanguinolentus (Herbst, 1783) (Decapoda, Brachyura, Portunidae) occurring in the coastal waters of Karachi, Pakistan. Fish. Res. 2010, 103, 56-62. [CrossRef]

79. McCarthy, L.C.; Loftus, W.F.; Rehage, J.S. Segregation of palaemonid shrimp along an Everglades estuarine gradient: Do multiple species have similar trophic function? Bull. Mar. Sci. 2012, 88, 843-861. [CrossRef]

80. Hamrin, S.F. Vertical distribution and habitat partitioning between different size classes of vendace, Coregonus albula, in thermally stratified lakes. Can. J. Fish. Aquat. Sci. 1986, 43, 1617-1625. [CrossRef]

81. Rountree, R.A.; Able, K.W. Diel variation in decapod crustacean and fish assemblages in New Jersey polyhaline marsh creeks. Estuar. Coast. Shelf Sci. 1993, 37, 181-201. [CrossRef]

82. Guest, M.A.; Connolly, R.M.; Loneragan, N.R. Seine nets and beam trawls compared by day and night for sampling fish and crustaceans in shallow seagrass habitat. Fish. Res. 2003, 64, 185-196. [CrossRef]

83. Hampel, H.; Cattrijsse, A.; Vincx, M. Tidal, diel and semi-lunar changes in the faunal assemblage of an intertidal salt marsh creek. Estuar. Coast. Shelf Sci. 2003, 56, 795-805. [CrossRef]

84. Dall, W.; Hill, B.; Rothlisberg, P.; Sharples, D. The Biology of the Penaeidae; Academic Press: San Diego, CA, USA, 1990; Volume 27, pp. 1-489.

85. Breckenridge, J.K.; Bollens, S.M. Vertical distribution and migration of decapod larvae in relation to light and tides in Willapa Bay, Washington. Estuar. Coas. 2011, 34, 1255-1261. [CrossRef]

86. Robertson, A.I.; Howard, R.K. Diel trophic interactions between vertically-migrating zooplankton and their fish predators in an eelgrass community. Mar. Biol. 1978, 48, 207-213. [CrossRef]

87. Robertson, A.; Klumpp, D. Feeding habits of the southern Australian garfish Hyporhamphus melanochir: A diurnal herbivore and nocturnal carnivore. Mar. Ecol. Progr. Ser. 1983, 10, 197-201. [CrossRef]

88. Unsworth, R.K.F.; Wylie, E.; Smith, D.J.; Bell, J.J. Diel trophic structuring of seagrass bed fish assemblages in the Wakatobi Marine National Park, Indonesia. Estuar. Coast. Shelf Sci. 2007, 72, 81-88. [CrossRef]

(C) 2020 by the authors. Licensee MDPI, Basel, Switzerland. This article is an open access article distributed under the terms and conditions of the Creative Commons Attribution (CC BY) license (http://creativecommons.org/licenses/by/4.0/). 